\title{
Refractory Arterial Hypotension in a Patient with COVID-19: Could the Hypothalamic-Pituitary-Adrenal Axis Be Involved? Case Report and Mini Review
}

\author{
Francisco E. Finamor ${ }^{*}$, Luciana P. Finamor ${ }^{2}$, Frederico J. N. Mancuso ${ }^{1}$, \\ Jaquelina S. Ota-Arakaki ${ }^{3}$, Marcelo R. S. Moraes' ${ }^{1}$, Cristina Muccioli², Nancy Bellei ${ }^{4}$ \\ ${ }^{1}$ Discipline of Emergency Medicine, Department of Medicine, Federal University of São Paulo, São Paulo, Brazil \\ ${ }^{2}$ Clinical Research Sector, Department of Ophthalmology, Federal University of São Paulo, São Paulo, Brazil \\ ${ }^{3}$ Discipline of Pneumology, Department of Medicine, Federal University of São Paulo, São Paulo, Brazil \\ ${ }^{4}$ Discipline of Infectious Diseases, Federal University of São Paulo, São Paulo, Brazil \\ Email: ^f.finamor@gmail.com
}

How to cite this paper: Finamor, F.E., Finamor, L.P., Mancuso, F.J.N., Ota-Arakaki, J.S., Moraes, M.R.S., Muccioli, C. and Bellei, N. (2020) Refractory Arterial Hypotension in a Patient with COVID-19: Could the Hypothalamic-Pituitary-Adrenal Axis Be Involved? Case Report and Mini Review. $A d$ vances in Infectious Diseases, 10, 160-167. https://doi.org/10.4236/aid.2020.103016

Received: August 3, 2020

Accepted: August 30, 2020

Published: September 2, 2020

Copyright $\odot 2020$ by author(s) and Scientific Research Publishing Inc. This work is licensed under the Creative Commons Attribution International License (CC BY 4.0).

http://creativecommons.org/licenses/by/4.0/

\begin{abstract}
Neuro-endocrinological manifestations rarely are described in cases of SARSCoV-2. We describe a case of a previously hypertensive patient who presented COVID-19 and developed refractory arterial hypotension. In the investigation, low levels of ACTH and cortisol were observed, suggesting secondary adrenal insufficiency as the cause of refractory hypotension.
\end{abstract}

\section{Keywords}

ACTH, Hypocortisolism, COVID-19, Adrenal Insufficiency, Arterial Hypotension

\section{Background}

COVID-19 is an acute respiratory infection caused by Severe Acute Respiratory Syndrome Coronavirus 2 (SARS-CoV-2). In addition to the respiratory features, the disease may affect multiple organs including the cardiovascular system [1]. Human Coronavirus ( $\mathrm{HCoV}$ ) family also has the potential to affect the Central Nervous System (CNS) and cause a variety of symptoms. Neuro-endocrinological manifestations are less understood and rarely have been reported [2].

The disease starts with the entry of SARS-CoV-2 into the respiratory system. It uses angiotensin-converting enzyme 2 (ACE2) as a receptor to ingress into 
host pneumocytes. A significant number of endocrine organs express ACE2 receptor, including the adrenal glands and the pituitary [3]. Autopsy studies on patients who died from SARS, had shown degeneration and necrosis of the adrenal cortical cells. Hence, it is likely that cortisol dynamics may be altered in patients with SARS [4]. Hypothalamic-pituitary-adrenal (HPA) axis plays a fundamental role in the response to stress. Some studies on SARS suggested that SARS-CoV could impair this hormonal axis by different mechanisms. The virus was found in adrenal and pituitary glands of patients who died for SARS, so these organs could also represent a target of infection [3]. However, data relating HPA axis impairment in COVID-19 is scarce.

\section{Case Presentation}

A 50-year-old male working as a frontline physician at a tertiary hospital in São Paulo, Brazil, had initial symptoms of nasal obstruction, headache and back pain. At his personal medical history, he referred asthma, diabetes mellitus type 2, myocardial bridging and refractory Systemic Arterial Hypertension (SAH), despite the use of three antihypertensive drugs (Metoprolol succinate $100 \mathrm{mg}$, Losartan $100 \mathrm{mg}$ and Hydrochlorothiazide $25 \mathrm{mg}$ ). He was in regular use of Inhaled Corticosteroids (ICS) for the last 10 years (formoterol fumarate dihydrate $12 \mathrm{mcg}$ + budesonide $400 \mathrm{mcg}$ ) and oral hypoglycemic agents (metformin 2000 $\mathrm{mg}$, sitagliptin $100 \mathrm{mg}$ and empagliflozin $25 \mathrm{mg}$ ) (Table 1).

Chest Computed Tomography (CT) showed a focal ground-glass lesion in the lower portion of the left upper lung lobe (Figure 1); real time polymerase chain reaction (RT-PCR) for SARS-CoV-2 on nasopharynx swab tested negative. Evaluation of liver enzymes identified increased transaminases (AST: $88 \mathrm{mg} / \mathrm{dL}$, NR: 12 - $40 \mathrm{mg} / \mathrm{dL}$ and ALT: $134 \mathrm{mg} / \mathrm{dL}$, NR: 10 - $41 \mathrm{mg} / \mathrm{dL}$ ).

On the second day, the patient developed respiratory discomfort, strong headache, fever $\left(37.9^{\circ} \mathrm{C}\right)$ and asthenia. The peripheral oxygen saturation was 92\%. Another nasopharynx swab with quantitative RT-PCR for SARS-CoV-2 was performed, at this time testing positive. The cycle threshold value $(\mathrm{Ct})$ of RT-PCR was 34 (Ct cut-off $<38$ for gene targets considered positives) which

Table 1. Highlights.

\begin{tabular}{|c|c|c|c|c|c|}
\hline Gender & Age & Comorbidities & Previous Medication & Pre COVID-19 health history & Post COVID-19 follow up \\
\hline Man & 50 & $\begin{array}{ll}\text { - } & \text { Refractory Systemic } \\
& \text { Arterial Hypertension } \\
\text { - } & \text { Asthma } \\
\text { - } & \text { Diabetes Mellitus type } 2 \\
\text { - } & \text { Myocardial bridging }\end{array}$ & $\begin{array}{l}\text { - Metoprolol succinate } 100 \mathrm{mg} \\
\text { - } \text { Losartan } 100 \mathrm{mg} \\
\text { - Hydrochlorothiazide } 25 \mathrm{mg} \\
\text { - Inhaled Corticosteroid: } \\
\text { formoterol fumarate dihydrate } \\
12 \mathrm{mcg}+\text { budesonide } 400 \mathrm{mcg} \\
\text { - metformin } 2000 \mathrm{mg} \\
\text { - } \text { sitagliptin } 100 \mathrm{mg} \\
\text { - empagliflozin } 25 \mathrm{mg}\end{array}$ & $\begin{array}{l}\text { The case refers to a } \\
\text { caucasianphysician from } \\
\text { Brazil that, inspite of regular } \\
\text { use of } 3 \text { antihypertensive } \\
\text { drugs, reports previous } \\
\text { Systemic Arterial } \\
\text { Hypertension of difficult } \\
\text { control. These data were } \\
\text { confirmed through patient's } \\
\text { medical records. }\end{array}$ & $\begin{array}{l}\text { - After } 2 \text { months of the } \\
\text { initial symptoms, the } \\
\text { patient remains with } \\
\text { normal blood pressure } \\
\text { levels (without } \\
\text { antihypertensive drugs) } \\
\text { and symptoms of memory } \\
\text { lapses and mild fatigue. } \\
\text { - Interestingly, very low } \\
\text { serum levels of ACTH and } \\
\text { Cortisol are still present. }\end{array}$ \\
\hline
\end{tabular}




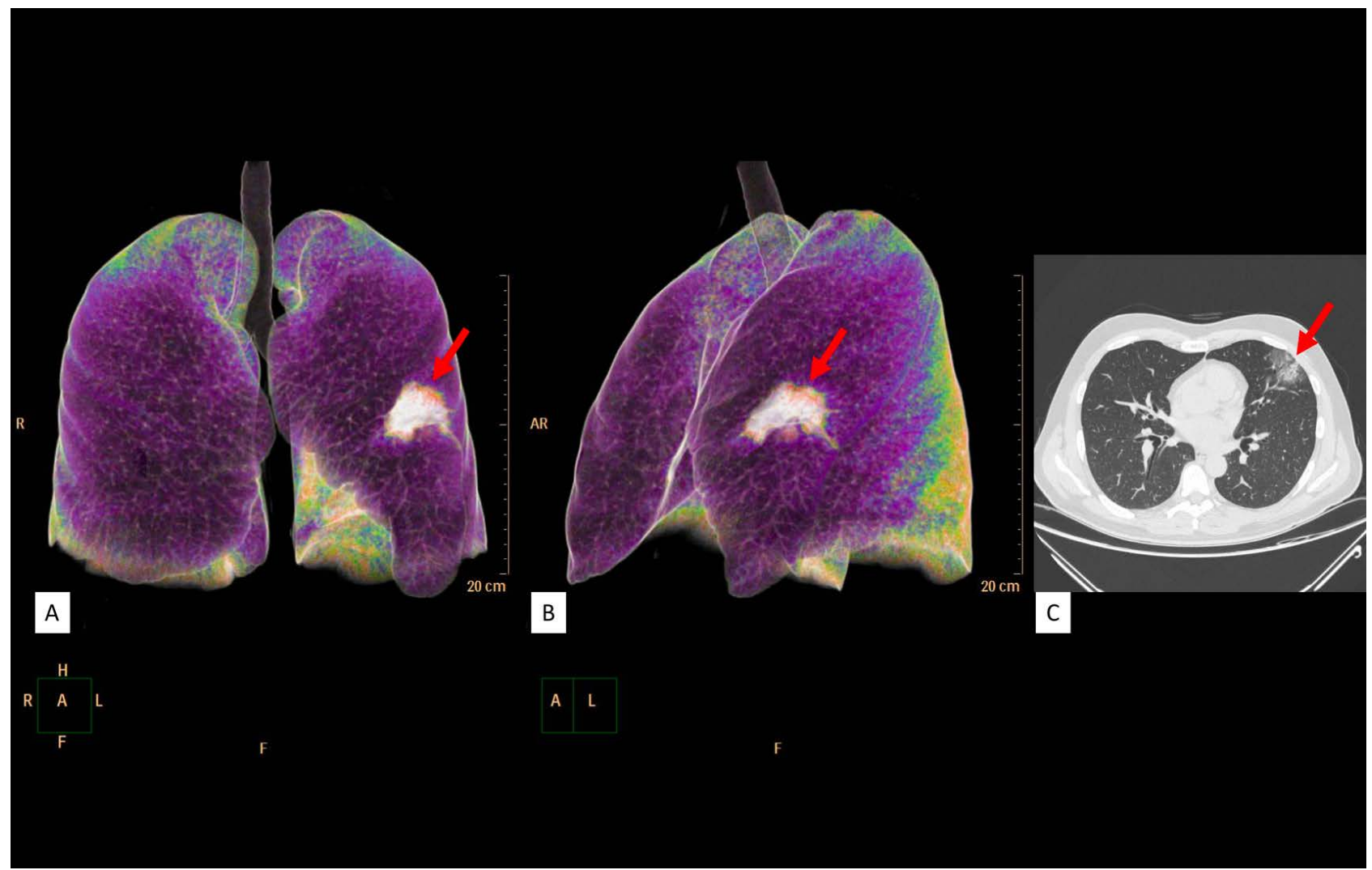

Figure 1. ((A)/(B)) Chest Volume Rendering Tomography (C) Chest Computed Tomography (CT). Arrows show a focal ground-glass lesion and consolidation in the lower portion of the left upper lung lobe.

probably represented the initial stage of the disease.

On the third day, the patient developed higher fever $\left(39^{\circ} \mathrm{C}\right)$, muscle weakness, worsening of respiratory distress and reduction of peripheral oxygen saturation (90\%). Hypotension $(90 \times 60 \mathrm{mmHg})$, tachypnea, tachycardia, dizziness, mental confusion and drowsiness were also observed. At this point, antihypertensive drugs were discontinued and he was admitted in a referenced hospital with an initial suspect of septic shock. New laboratory tests were performed, with no findings compatible with associated bacterial infection. Evaluation of electrolytes showed signs of mild dehydration. Leukocytes and lymphocytes count was normal ( 4.740 cells $/ \mathrm{mm}^{3}$ and 1.507 cells $/ \mathrm{mm}^{3}$, respectively). Platelets were at the lower limit of normality $\left(178,000 / \mathrm{mm}^{3}\right)$. D-dimer $(1.37 \mathrm{mcg} / \mathrm{mL}, \mathrm{NR}:<0.5 \mathrm{mcg} / \mathrm{mL})$ and ferritin levels (1500 ng/mL, NR: $23-336 \mathrm{ng} / \mathrm{mL}$ ) were increased; electrocardiogram and troponin levels were normal. Chest CT scan was repeated showing worsening of the initial lesion observed, still remaining unilateral and involving less than $25 \%$ of the left lung.

Volemic expansion was performed and preventive anticoagulant therapy with enoxaparin was started. Despite hydration, arterial pressure still remained low $(95 \times 65 \mathrm{mmHg})$. Nocturnal peripheral oxygen saturation levels dropped to $85 \%$ transiently, and oxygen support was needed.

On the fifth day, although still hypotensive, alleviation of initial presenting 
symptoms was observed, with improvement in drowsiness and mental state. Laboratory parameters were stable. A new nasopharyngeal sample was collected, and a RT-PCR was performed, showing a low Ct value of 18 for the gene target, suggesting a viral load higher than that initially found. He was discharged from the hospital and remained under home observation with daily care through telemedicine and home laboratory tests.

On the eleventh day, due to persistent fatigue and refractory hypotension, with complaints of muscle weakness, scotomas and dizziness, a new laboratory investigation was performed with the measurement of Adrenocorticotropic Hormone (ACTH), Cortisol, Thyroid Stimulating Hormone (TSH), Troponin, Creatine kinase $(\mathrm{CK})$ and $\mathrm{CKmb}$. An important reduction of ACTH $(<1 \mathrm{pg} / \mathrm{mL}$, NR: 7 - $63 \mathrm{pg} / \mathrm{mL}$ ) and Cortisol levels $(3.1 \mathrm{mcg} / \mathrm{dL}, \mathrm{NR}: 6-18.4 \mathrm{mcg} / \mathrm{dL})$ were observed. Echocardiogram, sodium, potassium, CK, CKmb, TSH and troponin levels were normal. Another nasopharyngeal swab was performed and a $\mathrm{Ct}$ value of 34 on rt-PCR showed a viral load clearance. The laboratory results are summarized in the Table 2.

The patient was started on methylprednisone $40 \mathrm{mg} /$ day and fludrocortisone $0.1 \mathrm{mg} /$ day, presenting improvement of fatigue, weakness and arterial pressure around the sixteenth day. Since the patient remained clinically stable, the medications were withdrawn after 30 days. Two months after the first symptoms of Covid-19, arterial pressure remained normal $(110 \times 70 \mathrm{mmHg})$ and the antihypertensive drugs have been definitely withdrawn. Serum levels of ACTH and Cortisol remained low (ACTH: 1 pg/mL, NR: 7 - 63 pg/mL and Cortisol: 0.7 microg/dl, NR: 6 - $18.4 \mathrm{mcg} / \mathrm{dL}$ ) and symptoms of mild fatigue and some memory lapses were still present.

\section{Discussion}

We report a case of a COVID-19 patient with previous uncontrolled SAH (despite the use of three antihypertensive drugs), controlled diabetes mellitus type 2 and asthma, in use of long-term ICS. In the early evolution of his condition, we highlight the appearance of signs and symptoms of mental confusion and hypotension, despite a minor pulmonary disorder observed in CT scan. Interestingly, the low saturation levels observed were disproportionate to the pulmonary imaging findings (Figure 1 ).

The first RT-PCR sample for SARS-CoV-2, during the oligosymptomatic phase, tested negative. However, the two following exams were positive. An increase in viral load was observed over the first five days of disease. These data were different from those described in literature which report that viral load in the upper respiratory tract appears to peak around the time of symptoms onset [5].

Neurologic manifestations in patients with coronavirus were described in $36.4 \%$ of hospitalized cases in a study from Wuhan [6]. Previous studies have shown the ability of SARS-CoV-2 to invade the brain through the nose, close to 
Table 2. Clinical and laboratory findings.

\begin{tabular}{|c|c|c|c|c|c|}
\hline & Day 1 & Day 2 & $\begin{array}{l}\text { Day } 3 \text { (Hospital } \\
\text { admission) }\end{array}$ & Day 5 & Day 11 \\
\hline Rt-PCR COVID 19 & Negative & Positive (Ct:34) & & Positive (Ct: 18) & Positive (Ct: 34$)$ \\
\hline Signs and Symptoms & $\begin{array}{l}\text { Nasal obstruction, } \\
\text { Headache, back pain }\end{array}$ & $\begin{array}{l}\text { Respiratory } \\
\text { discomfort, } \\
\text { strong headache, } \\
\text { fever }\left(37.9^{\circ} \mathrm{C}\right) \text {, } \\
\text { asthenia }\end{array}$ & $\begin{array}{l}\text { Hypotension } \\
\text { Mild dehydration } \\
\text { Fever }\left(39^{\circ} \mathrm{C}\right) \text {, muscle } \\
\text { weakness, tachypnea, } \\
\text { tachycardia, dizziness, } \\
\text { mental confusion, } \\
\text { drowsiness }\end{array}$ & $\begin{array}{l}\text { Hypotension } \\
\text { Alleviation of initial } \\
\text { presenting symptoms, } \\
\text { improvement in drowsiness } \\
\text { and mental state }\end{array}$ & $\begin{array}{l}\text { Hypotension } \\
\text { Tachycardia } \\
\text { Fatigue, muscle } \\
\text { weakness, scotomas } \\
\text { dizziness }\end{array}$ \\
\hline Arterial Pressure & $\begin{array}{l}150 \times 95 \mathrm{mmHg} \\
\text { (in use of } 3 \\
\text { antihypertensive } \\
\text { drugs) }\end{array}$ & & $\begin{array}{l}90 \times 60 \mathrm{mmHg} \text { (without } \\
\text { antihypertensive drugs) }\end{array}$ & $\begin{array}{l}90 \times 60 \mathrm{mmHg} \text { (without } \\
\text { antihypertensive drugs) }\end{array}$ & $\begin{array}{l}90 \times 60 \mathrm{mmHg} \text { (without } \\
\text { antihypertensive drugs) }\end{array}$ \\
\hline Sodium mmol/l & & & 141 (NR: 137 - 148) & 145 (NR: 137 - 148) & 140 (NR: 137 - 148) \\
\hline Potassium mmol/l & & & $3.9(\mathrm{NR}: 3.5-5.0)$ & $3.2(\mathrm{NR}: 3.5-5.0)$ & $4.1(\mathrm{NR}: 3.5-5.0)$ \\
\hline AST mg/dl & 88 (NR: 12-40) & & & 52 (NR: $12-40)$ & \\
\hline ALT mg/dl & 134 (NR:10-41) & & & 117 (NR:10 - 41) & \\
\hline DHL U/L & 550 (NR: $240-480$ ) & & & 319 (NR: $240-480$ ) & \\
\hline Leukocytes cells $/ \mathrm{mm}^{3}$ & & & 4.740 & 5.580 & 3.510 \\
\hline Lymphocytes cells $/ \mathrm{mm}^{3}$ & & & 1.507 & 2.290 & 1.110 \\
\hline Platelets cells $/ \mathrm{mm}^{3}$ & & & 172.000 & 178.000 & 179.000 \\
\hline d-dimer mcg/ml & & & $1.37(\mathrm{NR}<0.5)$ & $0.37(\mathrm{NR}<0.5)$ & \\
\hline Ferritin ng/ml & & & 1.500 (NR: 23 - 336) & & \\
\hline Troponin ng/ml & & & $<0.16(\mathrm{NR}:<0.16)$ & $<0.16(\mathrm{NR}:<0.16)$ & $<0.16(\mathrm{NR}:<0.16)$ \\
\hline ECG & & & Normal & & Normal \\
\hline Chest CT & $\begin{array}{l}\text { Focal ground lesion } \\
<25 \%\end{array}$ & & $\begin{array}{l}\text { Focal ground lesion }< \\
25 \%\end{array}$ & & \\
\hline Echocardiogram & & & & & Normal \\
\hline Oxygen Saturation & $96 \%$ & $92 \%$ & $85 \%$ & $90 \%$ & $90 \%$ \\
\hline ACTH pg/ml & & & & & $<1$ (NR: 7 - 63) \\
\hline Cortisol mcg/dl & & & & & 3.1 (NR: 6 - 18.4) \\
\hline TSH mui/l & & & & & 0.81 (NR: $0.45-4.5$ ) \\
\hline $\mathrm{CK} \mathrm{U/L}$ & & & & & 49 (NR:38 - 174) \\
\hline $\mathrm{CKmb} \mathrm{mg} / \mathrm{ml}$ & & & & & $0.8(\mathrm{NR}:<5.0)$ \\
\hline
\end{tabular}

the olfactory epithelium, causing olfactory and/or gustatory dysfunctions [5]. In this case, anosmia was not reported, but the first manifestation presented was an important nasal obstruction followed by headache. Mental confusion, dizziness and drowsiness were also observed. These clinical manifestations could be associated with a mild neurological condition.

Patients with COVID-19 can develop cardiovascular manifestations, with a 
variety of clinical presentations, such as cardiomyopathy, arrhythmias, and hemodynamic instability [1]. In this case, refractory arterial hypotension was observed in a previously hypertensive patient. Also, cardiovascular evaluation using echocardiogram, electrocardiogram, cardiac enzymes and troponin was normal. After volemic expansion, with the patient hydrated, blood pressure levels maintained low. Currently the patient is normotensive, even 2 months after the onset of the disease.

Hypothalamic-pituitary-adrenal axis plays a fundamental role in the response to stress. Adrenal insufficiency can be caused by a primary disease of the adrenal, usually presenting low levels of cortisol and high levels of ACTH levels; or secondary to hypothalamic-pituitary dysfunction, characterized by low levels of ACTH and disproportionately low levels of cortisol [7]. In the reported case, low levels of cortisol and ACTH were observed, characterizing the diagnosis of central or secondary adrenal insufficiency.

The clinical features of adrenal insufficiency are unspecific and include weakness, arterial hypotension, and dehydration [3]. A recently proposed hypothesis was that SARS-CoV-2 mediates inflammation of nucleus tractus solitarius (NTS), that could be responsible for the cytokine storm in COVID 19. The inflamed NTS could result in a dysregulation of the cholinergic anti-inflammatory pathway and HPA axis [2]. According to a SARS study, one of the primary strategy utilized by the SARS-CoV, is to knock down the host's cortisol stress response. SARS-CoV expresses certain amino acid sequences that act as molecular mimics of the host ACTH. Also, antibodies produced by the host to counteract the virus, in turn, would unknowingly destroy the producing ACTH cells in the pituitary gland, thereby blunting the cortisol rise [8]. SARS-CoV has a genome similar to that of SARS-CoV-2, so it may be possible to share physiopathological aspects and clinical manifestations.

Another study found that $39.3 \%$ of the patients with SARS had hypocortisolism; and among them, $83.3 \%$ had central adrenal insufficiency. They concluded that adrenal insufficiency could be a late consequence of SARS and it seemed to be secondary to hypophysitis or to direct hypothalamic damage [9]. It has also been postulated that SARS survivors, during clinical follow-up revealed a cluster of chronic extrapulmonary symptoms such as lethargy, fatigue, orthostatic dizziness, apathy, anxiety and depression [10]. However, to date, insufficient data is available to determine the exact effects of SARS-CoV-2 on the HPA axis function, and literature describes that any acute critical illness can lead to suppression of this axis, biochemically manifesting as low ACTH and cortisol levels [3] [4].

Regarding the treatment of adrenal insufficiency, substitutive therapy with glucocorticoid and/or mineralocorticoid should be started as soon as the diagnosis is confirmed in other acute hypocortisolism situations [7]. In this reported case, symptoms of hypocortisolism, probably due to a secondary adrenal insufficiency, were observed in the initial phase of the disease. As far as we know, there 
is no current treatment protocols for cases where hypocortisolism is associated with COVID-19. The aim of initial management in adrenal crisis is to treat hypotension, hyponatremia and hyperkalemia, and to reverse glucocorticoid deficiency. In the presented case, disturbance of sodium and potassium balance were not observed.

The important clinical improvement of the symptoms and the restoration of the normal arterial pressure after glucocorticoid and mineralocorticoid therapy reinforces the possible pituitary-adrenal axis damage by the virus and the consequent secondary adrenal insufficiency. After 2 months of the initial symptoms, the patient remains with normal blood pressure levels (without antihypertensive drugs), symptoms of mild fatigue and some memory lapses. Interestingly, very low serum levels of ACTH and Cortisol values are still present. The HPA axis dysfunction in a previous SARS study showed that most cases resolved within a year [9].

Our findings highlight a possible aetiologic role of COVID-19 in causing hypophysitis or a direct hypothalamic-pituitary-adrenal effect. Neuroimaging studies may be needed to better elucidate these situations. The impact of COVID-19 on patients previously using systemic steroids or ICS, should also be considered. Optimal glucocorticoid replacement therapy for patients with adrenal insufficiency is still controversial due to lack of evidence from randomized trials, so further studies are necessary for a better understanding of these mechanisms and their treatment.

\section{Conflicts of Interest}

The authors declare no conflicts of interest regarding the publication of this paper.

\section{References}

[1] Lindner, D., Fitzek, A., Bräuninger, H., et al. (2020) Association of Cardiac Infection with SARS-CoV-2 in Confirmed COVID-19 Autopsy Cases. JAMA Cardiology. https://doi.org/10.1001/jamacardio.2020.3551

[2] Ur, A. and Verma, K. (2020) Cytokine Storm in COVID19: A Neural Hypothesis. ACS Chemical Neuroscience, 11, 1868-1870. https://doi.org/10.1021/acschemneuro.0c00346

[3] Pal, R. and Banerjee, M. (2020) COVID-19 and the Endocrine System: Exploring the Unexplored. Journal of Endocrinological Investigation, 2, 1-5. https://doi.org/10.1007/s40618-020-01276-8

[4] Pal, R. (2020) COVID-19, Hypothalamo-Pituitary-Adrenal Axis and Clinical Implications. Endocrine, 68, 251-252. https://doi.org/10.1007/s12020-020-02325-1

[5] Wiersinga, W.J., Rhodes, A., Cheng, A.C., Peacock, S.J. and Prescott, H.C. (2020) Pathophysiology, Transmission, Diagnosis, and Treatment of Coronavirus Disease 2019 (COVID-19): A Review. JAMA. https://doi.org/10.1001/jama.2020.12839

[6] Mao, L., Jin, H., Wang, M., et al. (2020) Neurologic Manifestations of Hospitalized Patients with Coronavirus Disease 2019 in Wuhan, China. JAMA Neurology, 77, 1-9. https://doi.org/10.1001/jamaneurol.2020.1127 
[7] Falorni, A., Minarelli, V. and Morelli, S. (2013) Therapy of Adrenal Insufficiency: An Update. Endocrine, 43, 514-528. https://doi.org/10.1007/s12020-012-9835-4

[8] Wheatland, R. (2004) Molecular Mimicry of ACTH in SARS-Implications for Corticosteroid Treatment and Prophylaxis. Medical Hypotheses, 63, 855-862. https://doi.org/10.1016/j.mehy.2004.04.009

[9] Leow, M.K., Kwek, D.S., Ng, A.W., Ong, K.C., Kaw, G.J. and Lee, L.S. (2005) Hypocortisolism in Survivors of Severe Acute Respiratory Syndrome (SARS). Clinical Endocrinology $(O x f), 63,197-202$. https://doi.org/10.1111/j.1365-2265.2005.02325.x

[10] Tso, E.Y., Tsang, O.T., Choi, K.W., et al. (2004) Persistence of Physical Symptoms in and Abnormal Laboratory Findings for Survivors of Severe Acute Respiratory Syndrome. Clinical Infectious Diseases, 38, 1338. https://doi.org/10.1086/383580 